\title{
Tri tváre bez mena. Analýza portrétov zo zbierok Stredoslovenského múzea v Banskej Bystrici
}

\author{
DOI: https://doi.org/10.24040/ahn.2020.23.02.236-252
}

Zabezpečovanie odbornej ochrany zbierkových predmetov v kultúrnych inštitúciách priamo vyplýva $\mathrm{z}$ aktuálne platného zákona o múzeách a galériách a patrí k základnej činnosti odborných pracovníkov kurátorov. Vzhl'adom na úspešný projekt z Fondu na podporu umenia boli v roku 2019 a 2020 zreštaurované tri vzácne historické portréty, ktoré pochádzajú zo zbierok Stredoslovenského múzea v Banskej Bystrici (d'alej len SSM). Ide o portréty neznámych osobností, ktoré neboli pred reštaurovaním bližšie identifikované ani z hl'adiska personálnej identity, ani umelecko-výtvarného rozboru. Reštaurovanie prinieslo viacero podstatných informácií, na základe ktorých je možná ich následná vedecko-výskumná komparácia.

\section{Stručné vymedzenie problematiky}

Vo všetkých troch prípadoch portrétov (závesných obrazov) ide o olejomal'bu na plátne. Prvé dva portréty boli na reštaurovanie vytipované zo stálej expozície v Matejovom dome, nakol'ko ich technický stav nebol dobrý a nezodpovedal prezentačnému účelu. Posledný portrét bol vyhl'adaný $\mathrm{v}$ depozite. Portrét $\mathrm{z}$ depozitu zobrazujúci mladú ženu s erbom publikovala Danuta Učníková v roku 1980, pričom už vtedy vykazoval viaceré poškodenia. Vzhl'adom na mieru poškodenia nemohli portréty slúžit' na prezentačné ani vedecko-výskumné účely, pretože ich technický stav bránil identifikácii a následne vhodnej interpretácii.

Problematiku portrétu v kontexte vizuálneho umenia na území Slovenska rozpracovala $v$ minulosti D. Učníková, ${ }^{1}$ ktorá početné portréty v Stredoslovenskom múzeu v Banskej Bystrici aj popísala. Viacero portrétovaných patrí medzi významné osobnosti kultúrnohistorického, náboženského, politického a ekonomického života Banskej Bystrice $\mathrm{v}$ minulosti. Autorka sa zameriavala najmä na faktografické poznatky a identifikovanie konvergentných a divergentných prvkov analyzovaných portrétov. Aktualizovanú reflexiu problematiky portrétu vo výtvarnom umení a jeho interpretácie pre umenie na území Slovenska prinášajú Ingrid Halászová, ${ }^{2}$ Katarína Ihringová a Renata Kišoňová.

\footnotetext{
1 UČNÍKOVÁ, Danuta: Historický portrét na Slovensku. Bratislava, 1980.

2 HALÁSZOVÁ, Ingrid: Objekty pôvabu a úžitku. Kapitoly z dejín úžitkového umenia na Slovensku. Trnava : FF TU, 2017. Dostupné online: https://www.academia.edu/37310 
Uplatňujú kombináciu rôznych pohl’adov a prístupov k portrétu naprieč jednotlivými historicko-umeleckými obdobiami ako i filozoficko-estetickými základmi. Definujú tri východiskové body - kreovaná rétorika obrazu, antropológia imaginárna a hermeneutika symbolov, ktoré sa navzájom križujú a pretínajú. Vychádzajú z charakteristík portrétu, ktoré rozpracovali E. Gombrich, P. Burke, H. Belting. Portrét zverejňuje viditel'né, ale fyzická stránka modelu je podriadená dosiahnutiu objektívnej a výstižnej portrétnej reprezentácie identity „čitatel'nej“ pre daný kultúrny okruh. Neviditel'né je zviditel'nené pomocou symbolickej formy, ktorá zohl'adňuje konvencionalistické prvky správania (pózy, gestá, mimiku), atribúty (portrétne a stavovské rekvizity) a vizuálnu hodnotu krásy. Intelektový portrét bol konštruktom „idey“ a "formy“, čo sa v 17. storočí zvlášt' uplatňovalo pri reprezentačných účinkoch (najmä) vladárskych portrétov.

Portréty zo zbierok Stredoslovenského múzea disponujú a obsahujú zaužívané kódy a znaky, na základe ktorých je možné ich analyzovat', pričom musíme vychádzat' $\mathrm{z}$ konfrontácie poznatkov z oblastí módy, historického vývoja textilu (napr. M. Zubercová - E. Hasalová a kol., ${ }^{3}$ D. Martanová4) či šperkárstva (napr. B. Balážová5).

\section{Vizuálne kódy a rozpoznávanie identity}

Portrét, registrovaný v zbierkovom fonde SSM pod ev. č. Vu-01021, je na evidenčnej karte z roku 1968 identifikovaný ako Podobizeň mladej dámy zo šl'achtického rodu Radvanských, s monogramom „A.D.R 1703“. Katalogizačný lístok spracovala Danuta Učníková. Datovanie diela priamo vyplývalo z datovania na averze obrazu, pričom dielo nebolo zaradené do žiadneho umeleckého okruhu (resp. k umelcovi). Starší opis, ktorý realizoval Kornel Divald identifikoval monogram ako „A. D. K.“ (tzn. zmenené bolo posledné písmeno). V prírastkovej knihe a ani $\mathrm{v}$ prvých záznamoch K. Divalda nie je zmienka o tom, že by obraz pochádzal z majetku Radvanských. Tento údaj bol dodatočne ceruzou pozna-

728/_OBJEKTY_P\%C3\%94VABU_A_\%C3\%9A\%C5\%BDITKU_Kapitoly_z_dej\%C3\%ADn_\% C3\%BA\%C5\%BEitkov\%C3\%A9ho_umenia_na_Slovensku [prístup 20. 7. 2020]; HALÁSZOVÁ, Ingrid - IHRINGOVÁ, Katarína - KIŠOŇOVÁ, Renáta: Hl'adanie identity v portrétnom umení. Trnava : FF TU, 2019; HALÁSZOVÁ, Ingrid: Pred portrétom. Úvahy o obsahoch, významoch, funkciách a reprezentačných stratégiách portrétu v ranom novoveku. Trnava : FF TU, 2020.

3 ZUBERCOVÁ, Magdaléna - HASALOVÁ, Eva - ŠIDLÍKOVÁ, Zuzana - VANČO, Martin: Móda na Slovensku - stručné dejiny odievania. Bratislava : Slovart, 2014.

${ }^{4}$ MARTANOVÁ, Dominika: Vývoj odevných súčastí ženského uhorského odevu na Slovensku. Diplomová práca. Trnava : Trnavská univerzita, 2009.

${ }^{5}$ BALÁŽOVÁ, Barbara: Zlatníctvo stredoslovenských banských miest v ranom novoveku. Majstrovský objekt - životná investícia - elitná reprezentácia. Bratislava : Devin Printing House, 2016. 
čený až na evidenčnej karte z roku 1968, pričom nie je uvedené, na základe čoho došlo k spojeniu obrazu a zbierky diel Radvanských. Prvý dochovaný súpis tejto zbierky bol vyhotovený štátnym konzervátorom prof. Karolom Kiszelym v roku 1937,6 druhý v roku 1957 Gejzom Balašom, vtedajším prednostom Pôdohospodárskeho archívu, pri prevzatí zbierok do Stredoslovenského múzea. Oba súpisy však jednoznačne identifikujú len vel'mi málo portrétov - hlavne podobizne predstavitel'ov štátu a rodinných príslušníkov rodu Radvanských a Bárczayovcov. Na základe uvedených súpisov je tak vel'mi t’ažké identifikovat' jednotlivé diela, ktoré sa z kaštiel'a Radvanských dostali do zbierok SSM. V prvom vydanom Sprievodcovi mestského múzea v Banskej Bystrici (z roku 1937) ${ }^{7}$ sú spomínaní darcovia, ktorí prispeli k tvorbe zbierkového fondu, pričom je medzi nimi aj A. Radvanský, ale konkrétne dary nie sú uvedené. Nepomôže nám ani evidencia diel v najstarších prírastkových knihách, pretože málokedy obsahuje provenienciu, presný dátum získania či darcu predmetu. Spätne rekonštruovat' súvislosti je preto takmer nemožné (resp. značne hypotetické, bez relevantných dôkazov).

Prvý portrét mladej, dôstojnej a vážnej dámy je mal'ovaný na oválnom plátne. Sekundárne bol už v minulosti upravovaný (natiahnutý a fixovaný na novší podrám bez potrebnej profilácie). Po odbornom očistení obrazu bol zhodnotený technický stav zachovania originálnej vrstvy mal'by a následne bola stanovená metodika obnovy, ktorá vychádzala z rešpektovania originálu a aplikovania napodobivej retuše a vo výrazne poškodených miestach aj uplatnenia rekonštrukcie. Najviac poškodené boli okraje plátna, kde na mnohých miestach došlo k vypadaniu mal'by, pričom bola odhalená väzba plátennej podložky. Výrazné prešúchanie (takmer až na podklad) sa nachádzalo v mieste šnurovania na živôtiku a zástere. Na základe analógií, reštaurátor rešpektoval dochovaný stav a mierne podporil vizuálny výraz šnurovania a modelácie priesvitnej zástery, lemovanej čipkou s pravidelným „peniažkovým" vzorom.

Po odstránení prachu, špiny a depozitov, ako aj stmavnutého laku sa zretel'nejšie objavil na pozadí zelený zamatový záves na okraji so zlatými strapcami, ktorý lemuje portrét. Portrétovaná je zobrazená z jej pravej strany, ako $3 / 4$ portrét. Vo svojej pravej ruke drží ve-

\footnotetext{
${ }^{6}$ Karol Kiszely (Károly Kiszely) bol knihovníkom, kustódom a štátnym konzervátorom pôsobiacim v Mestskom múzeu v Banskej Bystrici. Jeho súpis obsahoval inventár zoradený podl'a jednotlivých miestností v kaštieli v Radvani. Podl’a jeho správy boli starožitnosti v dobrom stave, ale nie všetky boli určené a datované. Podl'a: SKLENKA, Vladimír a kol.: Radvaň. Banská Bystrica : CEPROCER, 2014, s. 175 - 182.

7 Publikácia Sprievodca mestského múzea v Banskej Bystrici (z roku 1937) je evidovaná SSM pod č. 6179.
} 
jár, ${ }^{8}$ v l'avej kvet tabaku ${ }^{9}$ (doposial' identifikovaný ako kvet l'alie - symbol čistoty a nevinnosti). Šaty sú svetločervenej farby, na živôtiku so šnurovačkou, ${ }^{10}$ pričom sa zdá, že červená látka bola dekorovaná zlatým ornamentom. Červená stuha šnurovačky je na bokoch živôtika prevliekaná cez zlaté úchytky - očká bohato zdobené ornamentom. Očká boli zrejme tiež zlatníckou prácou, nejde o výšivku. Aby šnurovanie vyšívanou stuhou viac vyniklo, bola predná čast' živôtika ušitá zo svetlo šedej látky. Biele naberané rukávy sú nad lakt'ami previazané saténovo lesklými, bielo-červenými mašlami (na červených pruhoch sa objavujú drobné žlté kvietky). Krajka na rukávoch (manžetách) má identický ornamentálny „peniažkový“ detail ako na okraji bielej, priesvitnej zástery z jemného závojového hodvábu. Dekolt je prekrytý čiernou krajkou, dekorovanou na hrudi brošňou $\mathrm{v}$ tvare čiernej mašle so stredovou rozetkou, tvorenou čiernymi drahokamami a perlovým ornamentom na bokoch, vytvoreným navliekaním na drôt. V strede visí vel'ká perla ako dominantný prvok. Čierna krajka je jemná a obsahuje rastlinný motív - štylizovanú ružu s rozvilinami. Výrazne pripomína bud' flanderskú, alebo bruselskú krajku, resp. môže íst' o štýl francúzskej šitej krajky, ktorá sa nazýva aleçonská - point d'Aleçon. Podobne vyzerala aj krajka z Argentanu - point d'Argentan. ${ }^{11}$ Na hlave má čierny čipkový čepček, pod ktorým má na hladko sčesané vlasy. Čepček uzatvára na zátylku lem zdobený perlami na zlatých kovových drôtikoch. $V$ strede zalamovaných vlniek sa nachádzajú drobné zlaté rozetky, uprostred sčiernym drahokamom. Korunka tvorí súpravu spolu s náhrdelníkom a brošňou na hrudi. Súprava je znakom skutočnej zámožnosti portrétovanej. Krk je dekorovaný štyrmi radami bielych perál. Napriek jeho datovaniu (1703) bol obraz ešte vytvorený v duchu renesančného, statického konceptu. Z umeleckovýtvarného hl'adiska ide o kvalitatívne hodnotný portrét.

\footnotetext{
${ }^{8}$ Vejár bol typickým atribútom a doplnkom portrétov dám. Ich popularita vzrástla od 16. storočia a udržala sa do 18. storočia. Okrem ochladzovania slúžili i k spoločenskej komunikácii. V Španielsku sa na konci 16. storočia vytvorila akási reč vejára, ktorá mala vel'ký úspech v nasledujúcom storočí po celej Európe. Viac pozri: VAŇKOVÁ, Lenka - PILNÁ, Veronika: Metodika datování a interpretace portrétů 16. - 18. století pomocí historické módy. Praha : NPÚ, 2014, s. 79; KYBALOVÁ, Ludmila - HERBENOVÁ, Olga - LAMAROVÁ, Milena: Obrazová encyklopedie módy, Praha : Artia, 1973, s. 482.

${ }^{9} \mathrm{Na}$ základe konzultácie by mohlo íst' o okrasnú kvetinu tabak krídlatý Nicotiana alata alebo Nicotiana x sanderae. V čase vzniku diela bol tabak v Európe už známy. Porovnaj: „Organizované pestovanie a predaj tabaku v Rakúsko-Uhorsku sa datuje už od roku 1670. Na území Slovenska, sa tabak začal pestovat' už v druhej polovici 16. storočia v okolí Hurbanova (predtým Stará Ďala). Tento tabak mal vysokú hodnotu aj za hranicami Uhorska. "Podl'a: https://smokemag.sk/historia-tabaku-na-slovensku/ [prístup 20. 7. 2020].

10 Podl'a záznamov K. Divalda boli šaty previazané červeno-bielou stuhou, tá však v súčasnosti už nebola čitatel'ná.

11 VAŇKOVÁ, L. - PILNÁ, V.: Metodika datování a interpretace portrétů 16. - 18. století, s. 75.
} 
Reštaurátor obzvlášt' obozretne postupoval pri čistení miesta, kde sa nachádza erb s monogramom tak, aby nedošlo k úbytkom a následne $\mathrm{k}$ interpretačným posunom. Tento hodnotný prvok bol zdokumentovaný viacerými neinvazívnymi metódami (pozorovanie pri razantnom osvetlení, UV, IČ, makro-fotografia stavu pred očistením) tak, aby bolo čo najviac možné odčítat' originálnu skladbu. Na základe detailného výskumu bolo možné potvrdit’ skladbu písmen „A. D. K.“ (nie „R“ na konci textu). Na základe poznatkov bolo zjavné, že erb nie je zhodný s erbom rodu Radvanských. Jednoznačne určil erb až Frederik Federmayer ${ }^{12}$ po porovnaní s erbovou pečat'ou z roku 1652, ktorá patrila šl'achticovi Martinovi Kayserovi, jednému z najbohatších patricijov a banských podnikatel'ov v Banskej Štiavnici. Vzhl'adom na erb možno ženu na portréte jednoznačne priradit’ $\mathrm{k}$ tomuto významnému rodu. $\mathrm{V}$ hornom strieborno-červeno štiepenom poli je skáčuci čierny jeleň (možno pôvodne prirodzenej farby), v dolnom zlatom poli nad sebou dva strieborné lovecké rohy so šnúrou, horný otočený nátrubkom vl'avo, dolný nátrubkom vpravo. Z turnajovej prilby splývajú vpravo modro-zlaté, vl'avo červeno-strieborné prikrývadlá. Klenotom je medzi strieborno-červeno a modro-zlato delenými krídlami rastúci strieborný jednorožec. Federmayer upozornil, že rod bol príbuzensky spriaznený $\mathrm{s}$ viacerými uhorskými aristokratickými rodmi a zároveň poukázal na skutočnost', že rod Radvanských v tom čase do tejto vyššej spoločnosti nepatril. Na základe výskumu sa F. Federmayerovi podarilo identifikovat' v druhej polovici 17. storočia dve ženy z tohto rodu, ktorým mohli patrit' iniciály A. D. K. Prvou bola Anna Kayser (doložená v roku 1658), manželka Abraháma Dióssyho alias Nussdorffera, richtára mesta Krupina. V tom prípade by sa iniciály dali rozviest' aj ako Anna Dióssy Kayserin. Druhou bola Anna Euphrosina Kayser, ktorá sa v roku 1683 vydala v Kremnici za Jeremiáša Schmidegga, popredného vzdelanca a patricija v Kremnici a Banskej Bystrici a zakladatel'a neskoršieho grófskeho rodu Schmideggovcov. U nej iniciály úplne nesedia, avšak bolo možné pripustit' alternatívu, že meno Euphrosina mohlo byt' vynechané.

Nakol'ko absentujú hodnoverné informácie o tom, kto daroval (či predal) obraz do SSM, a nie je jasné, z ktorého kaštiel'a pochádzal, bude v budúcnosti potrebné realizovat' hlbší podrobný výskum a analýzu kolekcie diel podl'a evidenčných čísel, ktoré sa nachádzajú bezprostredne pred alebo za evidovaným portrétom. Na základe zbežnej kontroly ide o rôznorodé portréty zo 17 . až 19 . storočia, pričom sa medzi nimi nachádzajú aj obrazy s krest’anskou ikonografiou.

\footnotetext{
12 Doc. PhDr. Frederik Federmayer, PhD. pôsobí na Katedre archívnictva a pomocných vied historických Filozofickej fakulty UK v Bratislave, venuje sa heraldike a genealógii.
} 
Pátranie po možných súvislostiach a vzt'ahoch nás priviedlo ku konfrontácii s osobnost’ami evidovanými v kolekcii mortuárií, ktoré sa nachádzajú vo fonde SSM. V časti zbierky pochádzajúcej z kaštiel’a v Radvani bolo identifikované mortuárium Karolíny von Örzen, ${ }^{13}$ vdovy po Tomášovi Teodorovi barónovi von Schmidegg, ktorá zomrela v roku 1735. V spolupráci s M. Hrdinovou a T. Janurom sa podarilo zistit', že Anna Eufrozína Kaiser bola matkou baróna Tomáša Teodora Leopolda Schmidegga ("1651 - †1726), ${ }^{14}$ ktorý istý čas vlastnil kaštiele v Hronseku. ${ }^{15}$ Po Schmideggovcoch sa ako vlastníci kaštiel'a objavujú aj členovia rodín, ktoré neskôr prispievali darmi do formujúcich sa zbierok vtedy ešte Mestského múzea (napr. Rothovci, Hamacsekovci). Uvedené súvislosti vedú $v$ tejto fáze poznania $k$ stotožneniu portrétovanej osoby s Annou Eufrozínou Kayser, pričom je vysoko pravdepodobné, že portrét sa nachádzal $v$ zbierke portrétov $v$ Hronseku. Bez podrobnejšieho archívneho a historického výskumu však nie je možné zistit', ako sa dostal jej portrét do zbierok SSM.

Druhý portrét, registrovaný v zbierkovom fonde SSM pod ev. č. Vu01022, je na evidenčnej karte z roku 1968 uvedený ako portrét neznámej ženy z 18. storočia (bez bližšej identifikácie autora diela alebo lokality). Na staršej evidenčnej karte, ktorú realizoval K. Divald je ceruzou poznačené, že na ráme obrazu sa nachádzal text, ktorý jednoznačne uvádza nasledujúce údaje: „Csernyánszky János... evan. farár... Schmirdeg (?) 1777“. Zároveň je uvedená aj poznámka, že „drevený rám je z pozdnejšej doby“. Nie je celkom zrejmé, či sa text nachádzal na drevenom podráme obrazu, alebo na dekoratívnom ráme. Na základe dostupných údajov je možné konštatovat', že evanjelický farár János Csernyánszky, ktorý pochádzal z Rajca ("1709 - †1766?) od roku 1740 pôsobil ako učitel', pričom jeho činnost' je zaznamenaná na viacerých miestach, o. i. aj v Banskej Bystrici a okolí. V čase realizovania reštaurátorského výskumu sme žial' nedokázali získat' podrobnejšie údaje z jeho života, ktoré by objasnili jeho rodinné pomery a spoločenské vzt'ahy. Obraz bol D. Učníkovou ${ }^{16}$ evidovaný a datovaný do rozmedzia rokov 1750 - 1760.

\footnotetext{
13 Janura uvádza prepis „barónka Charlotte Friderica Ortzen ("1672 - †1735)“ Podl'a: JANURA, Tomáš a kol.: Vidiecke šlachtické sídla v Zvolenskej stolici. Bratislava : Spoločnost' Kolomana Sokola, 2016, s. 95.

14 HRDINOVÁ, Martina a kol.: Mortuáriá zo zbierok Stredoslovenského múzea v Banskej Bystrici. Banská Bystrica : SSM, 2017, s. 234.

15 „Tomáš Teodor Leopold Schmidegg pochádza pôvodom zo saského rodu, ktorého členovia sa začiatkom 17. storočia usadili v Kremnici... Cisár Schmidegga za ... zásluhy 30. marca 1689 povýšil medzi uhorských barónov. V roku 1690 získal od panovníka menovanie za župana Zvolenskej stolice a následne sa stal uhorským král'ovským radcom". JANURA, T. a kol.: Vidiecke šl'achtické sídla v Zvolenskej stolici, s. 88 - 96.

16 UČNÍKOVÁ, D.: Historický portrét, s. 57.
} 
Zaradený bol medzi reprezentatívne portréty domáceho autora. V minulosti vybratý z rámu a už bez rámu bol prezentovaný aj v expozícii v Matejovom dome.

Tento obraz mal až dve sekundárne premal'by so snahou o zachovanie jeho hmotovej podstaty (obraz bol na troch miestach perforovaný). Prvá súvisela s poškodením nad hlavou zobrazovanej, kde bolo plátno perforované a neodborne zalepené. Pri tejto príležitosti bol obraz zrejme prvýkrát očistený a poškodený v niektorých pasážach mal'by, najmä tam, kde boli tenké lazúry na vrstve (napr. v miestach perál na krku a v plochách tmavších miest na šate zobrazovanej). Druhá celoplošná premal'ba súvisela zrejme $\mathrm{s}$ jeho poškodením v spodnej časti, kde vznikla pomerne vel'ká trhlina. Pri sekundárnej úprave došlo k premal'be pozadia a šatu karmínovou farbou, ktorá potláčala celkovú modeláciu drapérie. Na tomto prelepe sa zo zadnej strany našla matematická úloha z geometrie, kde sa na spodnej strane nachádza meno „Nathan Vilmoš...".

Portrét zobrazuje dámu v zlatom priliehavom čepci z kovových nití. Tento typ čepca sa často objavuje na portrétoch $\mathrm{z}$ banských oblastí17. Podl'a detailného priblíženia je možné uviest', že pravdepodobne išlo o paličkovanú krajku z kovových nití. Špička čepca vybieha mierne do čela. Šatka okolo krku je zdobená výšivkou na vel'mi jemnom podklade. Na prsiach je preložená tak, že cíp z pravej strany smeruje k l'avému boku a cíp z l'avej strany smeruje k pravému boku. Ide o výšivku tzv. hladkovaním, čo je technika plnej výšivky (ide o vyšívané pásky jemnej textílie, na obidvoch stranách zakončené obšitím v tvare vlnoviek, ktoré boli aplikované na šatku ako volány). Dekór výšivky má typické barokové vzory vychádzajúce z benátskej šitej krajky, ktorá bola cenovo ovel'a drahšia a na výrobu podstatne náročnejšia. Objavuje sa motív ruže, ale aj granátového jablka a drobných kvietkov, pospájaných do ornamentálnej celoplošnej kompozície. Podl'a zobrazenia kvality materiálu a nasadenia svetla (lesku) je možné identifikovat', že šaty boli vytvorené z červeného zamatu. Na krku je portrétovaná ozdobená piatimi radmi zlatých retiazok prevlečených hnedou šnúrkou. Ďalším šperkom je prsteň na malíčku ruky držiacej ružu. Prsteň je skladaný v tvare kvietka s rovnakých drahokamov. Zdvojené rukávy - vrchný širšie otvorený a spodný, ktorý obopína ruku pod lakt'om - svojim tvarom zodpovedajú vyššie uvedenému datovaniu portrétu D. Učníkovou okolo polovice 18. storočia. Portrétovaná drží v l’avej ruke zložený vejár a v pravej svetloružovú

\footnotetext{
${ }^{17}$ Aj v zbierkovom fonde SSM sa nachádza niekol'ko meštianskych čepcov z kovových nití, ktoré sú datované do 18. a neskôr aj 19. storočia. V niektorých prípadoch sú kombinované s textíliou, krajkou a stuhami. V dobe ich vzniku išlo o hodnotný artikel a je pravdepodobné, že boli vyrábané do tvaru a na mieru. Dedili sa z matky na dcéru. ZUBERCOVÁ, M. - HASALOVÁ, E. - ŠIDLÍKOVÁ, Z. - VANČO, M.: Móda na Slovensku, s. 78.
} 
ružu. Ruža bola vel'mi obl'úbeným symbolom, ktorý je bežne považovaný za nadčasové vyjadrenie lásky, úcty, viery, krásy, rovnováhy, vášne, múdrosti, oddanosti.

V zbierke SSM sa nachádza vel'mi príbuzný portrét dámy, kde je stojaca ženská postava odetá v obdobnom šate, pričom biely prehoz prekrýva celé plecia a živôtik. Na hlave má rovnako čepiec z čipky zo zlatých kovových nití. Má ovel’a bohatší perlový náhrdelník a perlové náušnice. Predpokladá sa, že ide o svadobný portrét, ale nie je určený a zaevidovaný je ako portrét neznámej dámy (ev. č. Vu-01024) bez d'alších identifikačných údajov. Atribúty (ružu a vejár) drží v opačných rukách ako dáma na portréte $\mathrm{s}$ ev. č. Vu-0122 a ruža je sýtočervenej farby. Podl'a fyziognómie portrétovaných dám však zrejme nejde o osoby v priamom príbuzenskom vzt'ahu.

Posledný portrét, registrovaný pod ev. č. Vu-01023, je na evidenčnej karte SSM rovnako len rámcovo popísaný. V názve je uvedené, že ide o „Portrét neznámej dámy“. Podl'a datovania by malo íst' o portrét z 18. storočia, pričom lokalita (proveniencia) a autor neboli jednoznačne identifikované. Starší evidenčný lístok, ktorý spracoval Kornel Divald, ${ }^{18}$ obsahuje informáciu, že ide „o portrét mladej ženy $v$ bielych hodvábnych šatách, zdobených širokou bruselskou čipkou, s obrubou z drahých kameňov. V pravej ruke drží ružu." Divald bližšie popisuje, že ide o obraz z „50. rokov 18. storočia“. D. Učníková19 predmetný obraz eviduje a identifikuje ako portrét Eleonóry, tretej manželky Leopolda I. Zároveň poukazuje na možného autora z „dvorského“ okruhu. Namiesto bielych šiat v popise uvádza, že Eleonóra je odetá v sivej (a nie bielej) róbe „podl'a francúzskej módy približne z roku 1635“ a obraz datuje do rozmedzia rokov 1680 - 1690, čiže do obdobia "reprezentatívneho baroka“. Ružu, ktorú drží v rukách považuje za „symbol ženského pôvabu“.

Podl'a opisov diela K. Divaldom a D. Učníkovou usudzujeme, že jeho technický stav a kondícia neboli dobré ani v čase, ked' bolo katalogizované. Divald pri opise obrazu síce identifikoval jasné detaily (napr. ružu) avšak celkom opomenul cisársku korunu, ktorá je jednoznačným identifikačným prvkom. Učníková namiesto bielych šiat

\footnotetext{
18 Glocko uvádza: „Kornel Divald zohral významnú úlohu pri zakladaní a formovaní budúceho Mestského múzea v Banskej Bystrici. Vytvorením prvej múzejnej expozície bol na návrh Viliama Fraknóia (1843 - 1924), rímskokatolíckeho kňaza, vel'kovaradínskeho kanonika, biskupa arbeského a uhorského historika, poverený Kornel Divald, pričom mu bol určený termín 15. september 1909. Divald sa stal scenáristom a aj realizátorom prvej muzeálnej expozície. S prácou začal 1. júna 1909, opísal viac ako dva a pol tisíc predmetov, teda všetky, ktoré sa v tom čase v múzeu nachádzali. Mineralogické a numizmatické predmety popísal Dr. Samuel Bothár. "Podl'a: GLOCKO, Filip: Kornel Divald. In: Radničné noviny mesta Banská Bystrica. roč. XIII, č. 2, február 2019, s. 12.

19 UČNíKOVÁ, D.: Historický portrét, s. 54.
} 
identifikovala sivé, pričom uviedla, že „tmavé vlasy splývajú v pozadí $s$ drapériou".

Vzhl'adom na sumarizáciu základných poznatkov bolo v prvej fáze reštaurátorského prístupu nutné zamerat' sa na odstránenie mastného a vol'ného prachového depozitu, ako aj nepravidelnej vrstvy stmavnutého laku, ktorý sa nachádzal po celej ploche obrazu, kvôli čomu bolo viacero detailov na obrazovej ploche nečitatel'ných Zároveň bolo nutné stabilizovat' a spevnit' maliarsku vrstvu, ktorá bola značne poškodená a skrakelovaná. Jej adhézia k podložke bola značne narušená. V spodnej časti pri l'avom okraji chýbalo väčšie množstvo farebnej a podkladovej vrstvy. Okraje plátna boli oslabené, $\mathrm{v}$ mieste preznačenia podrámu absentovala farebná vrstva, plátno a farebná vrstva boli zalomené. Po vizuálnej obhliadke bolo zrejmé, že plátenná podložka bola vyrezaná z väčšieho kompozičného celku (o čom svedčili absentujúce okraje plátna). Olejomal'ba nebola napnutá (následne nalepená) na profilovanom podráme, ktorý by zodpovedal dobovej tradícii, ale na podráme bez profilácie (tzn. nevyhovujúcom). Výrazne narušený technický stav obrazu, ktorý vykazoval viacero závažných poškodení znižoval kvalitu diela a jeho reprezentatívne určenie.

Po odbornom očistení a odstránení nevhodnej stmavnutej lakovej vrstvy bol portrét opätovne odborne prehodnotený. Na základe zhodnotenia reštaurátora obraz vytvoril zručný a školený maliar. Inkarnáty boli jemne modelované. Šperky a čipka, ktorá lemuje široký dekolt ${ }^{20}$ aj rukávy sú detailne vypracované. Podl'a porovnaní sa prikláňame $\mathrm{k}$ tomu, že ide o benátsku šitú krajku (nie bruselskú čipku). Ide o typ krajky so vzorom, ktorá sa vyrábala vo vrcholnej produkcii benátskych dielní. Bol to vel'mi drahý materiál - nakol'ko išlo o mimoriadne presnú krajku s motívom granátového jablka v kombinácii s rozvilinami. Materiál šiat na pevnom živôtiku (predíženého strihu, tvarovaného akoby do špice) ${ }^{21}$ je silne vypnutý, ale podl'a sukne by mohlo íst' o hodvábny ryps (vrúbkovanú tkaninu), ktorý mal dost' výrazný lesk. Usudzujeme tak podl'a spôsobu mal'by sukne a častí nadýchaných rukávcov, kde je vnímatel'né vrúbkovanie. Mašle boli pravdepodobne urobené $\mathrm{z}$ tenkého hodvábneho mušelínu. Na zdobenie sú použité polodrahokamy (alebo drahokamy, ako napr. čierny diamant, zafír alebo ónyx, používané aj v korunovačných klenotoch) v kombinácii bud' so sklenými perlami,

\footnotetext{
${ }^{20}$ Uplatnenie širokého dekoltu miskovitého tvaru odhal'ujúceho ramená bolo inšpirované francúzskou módou. Podl'a: VAŇKOVÁ, L. - PILNÁ, V.: Metodika datování a interpretace portrétů 16. - 18. století, s. 33.

21 Tvar šiat, okrem riešenia dekoltu, skôr zodpovedá doznievajúcim reminiscenciám na uzavretú španielsku módu. VAŇKOVÁ, L. - PILNÁ, V.: Metodika datování a interpretace portrétů 16. - 18. století, s. 32.
} 
alebo perlami vyrobenými z kryštálu. ${ }^{22}$ Po očistení aj nad’alej ostával účes tmavých vlasov mierne splývavý s pozadím (pričom dve lokne ohraničovali odhalené ramená mladej ženy), ${ }^{23}$ avšak výrazne sa objavila dekorácia závesu s brokátovaním a so strapcami.

Počas reštaurovania bol portrét porovnaný s dochovanými portrétmi (olejomal'bami i grafikami), ktoré zobrazujú cisárovnú Eleonóru. Na základe komparácie však bolo zistené, že portrétovaná mladá žena vykazuje omnoho viac zhodných znakov so zachovanými portrétmi (olejomal'bami aj grafikami) Klaudie Felicitas Tirolskej (1653 - †1676), druhej manželky cisára Leopolda I., s ktorou uzavrel manželstvo 5. októbra 1673 v Grazi. Jej otcom bol arcivojvoda Ferdinand Karol, príslušník vedl'ajšej tirolskej vetvy Habsburského rodu, a matkou bola Anna Medicejská, toskánska princezná, dcéra toskánskeho vojvodu Cosima II. Vd'aka tomuto zväzku sa pod Leopoldovu vládu vrátilo územie Tirolska a tzv. Predného Rakúska. Narodili sa im dve dcéry (v roku 1674 Anna Mária Žofia, 1675 Mária Jozefína Klementína), ktoré sa žial' nedožili ani prvých narodenín. V roku 1676 zomiera aj Klaudia Felicitas (pravdepodobne na tuberkulózu), ktorá od svojho sobáša neopustila Viedeň a nedočkala sa ani korunovácie za českú a uhorskú král'ovnú. Dnes je takmer zabudnutou postavou histórie.

Vzhl'adom na ich krátke manželstvo sa nezachovalo vel'a jej portrétov. Nasledujúcou manželkou Leopolda I. sa stala Eleonóra Magdaléna Terézia Falcko-Neuburská ("1655 - †1720), ktorá bola na prvých portrétoch zobrazovaná v rovnakom postoji ako Klaudia Felicitas. Šaty, šperky a rovnako aj typ účesu sú často zobrazované obdobne, takže mohlo dochádzat' k zámene postáv, avšak jednoznačným odlišovacím prvkom je farebnost' vlasov, ktoré mala Eleonóra Magdaléna, na rozdiel od tmavovlásky Klaudie Felicitas, svetlo plavé.

Počas reštaurovania predmetného obrazu sa podarilo nájst' takmer totožný obraz, kde je Klaudia Felicitas zachytená v skoro identických šatách (čo sa týka strihu, kvality i farebnosti) aj s takmer

\footnotetext{
${ }^{22} \mathrm{~V}$ tej dobe bol vel'ký dôraz pri šperkoch položený na materiály, ktorým sa všeobecnej pripisoval skrytý význam (do istej miery fungovali aj ako amulety). Náramky a prstene odkazovali na zámožnost' majitel'a. Prsteň na ruke ženy mohol byt' zároveň symbolom vernosti, ktorý dávala mužovi vo svadobný deň (takýto prsteň bol umiestňovaný na l'avú ruku). Mohlo však íst' aj o dar.

${ }^{23}$ Tento typ účesu vyčesaného dohora, pričom po stranách sú spustené dve lokne bol známy v rôznych krajinách pod rôznymi názvami, napr. v Nemecku - Korkenzieherlocken (korkové vývrtky), Schlangenlocken (hadie lokne) či Stöpsellocken (zátkové lokne). Používaný bol od 30. rokov 17. storočia, kedy sa dominantnejšie začali v móde presadzovat' francúzske vplyvy. Podl'a: KYBALOVÁ, Ludmila: Dějiny odívání. Barok a Rokoko, Praha : Lidové noviny, 1997, s. 72. Vlasy sa natáčali nielen kulmami, ale tiež sa namotávali na tzv. papiloty (primitívne natáčky).
} 
identickými čipkami a obdobnými šperkmi, ako aj závesom v pozadí (len zrkadlovo situovanom) a korunou, ktorá je položená na poduške pri postave. ${ }^{24}$ Totožná je aj úprava vlasov, ktorá je typická pre jej osobu. V strede čela má vlasy nakučeravené podl'a vtedajšej módy. Jedinou výraznou kompozičnou a významovou zmenou je poloha jej pravej ruky. Na obraze z aukcie drží v pravej ruke v smere od seba ríšske jablko. Na obraze zo zbierok SSM má ruku v geste smerom k sebe, pričom v nej drží bielu ružu, ktorá má hrany lupienkov červené. Podobný typ šiat zachytáva niekol'ko výtvarných diel ${ }^{25}$. Hlavu cisárovnej Klaudie so špecifickým účesom s kučierkami dokumentuje aj grafika Georga Andreasa Wolfganga ("1631 - †1716) uložená v Král'ovskej zbierke v Anglicku, pričom rešpektuje medirytinu s vyobrazením alegórie cisárskeho páru Leopolda I. a Klaudie Felicitas od rytca B. Kiliana (uložené v Tirolskom štátnom múzeu Ferdinandeum). ${ }^{26} \mathrm{Z}$ hl'adiska preberania vzorov a ich následného variovania je zaujímavý ako možný východiskový - reprezentačný - portrét z roku $1673,{ }^{27}$ kde sa opät' nachádza stojaca postava cisárovnej s pevným trojuholníkovým živôtikom s hlbokým pásom dekorovaným perlami, okrúhlym výstrihom odhal'ujúcim ramená, širšími rukávmi dekorovanými čipkou. Farba šiat je strieborno-sivá s aplikovaným zlatým ornamentom. Prítomné sú aj ostatné atribúty - cisárska koruna, záves na identickej strane ako na obraze zo SSM (obdobnej farebnosti aj s ornamentom). Zaujímavé je, že Klaudia Felicitas drží v rukách biely kvet - ružu. Ako sme už uviedli, symbol ruže bol vel'mi oblúbený a uplatňovaný pri portrétoch dám. Biela farba môže poukazovat' na jej cnostný charakter, nevinnost', čistotu, ale je aj vyjadrením rešpektu, úcty a nádeje do budúcnosti. Využívaná bola ako odkaz na nové začiatky alebo pri rozlúčke. Biela ruža si tiež dlho udržiavala postavenie spojené s čistou láskou a formálnymi obradmi, čo z nej robí viacúčelový kvet používaný pri rozličných ceremóniách ako sú výročia, krstiny či promócie (H. Biedermann, ${ }^{28} \mathrm{H}$. Rulíšek, ${ }^{29} \mathrm{U}$. Becker, ${ }^{30} \mathrm{~J}$. Hall ${ }^{31}$ ). Nejde o plne rozvitý kvet, čo môže byt' pou-

\footnotetext{
${ }^{24}$ Vol'ne dostupné: https://commons.wikimedia.org/wiki/File:Austrian_School_-_Probab le_portrait_of_Empress_Claudia_Felicitas.png. [prístup 20.7. 2020].

25 Vol'ne dostupné: https://www.dorotheum.com/en/l/440422/, https://www.rct.uk/ collection/613463/claudia-felicitas, https://www.gogmsite.net/casual_dress_-_1641_to_ 1683/subalbum-claudia-felicitas/1673-archiduquesa-claudia.html. [prístup 20. 7. 2020].

${ }^{26}$ Vol'ne dostupné: https://www.museum-joanneum.at/schloss-eggenberg-prunkraeume -und-gaerten/fuerstliche-residenz/gaeste-und-feste/kaiserhochzeit-1673. [prístup 20. 7. 2020].

${ }^{27}$ Vol'ne dostupná: http://internationalportraitgallery.blogspot.com/2014/12/retrato-de -la-emperatriz-claudia.html?spref=pi. [prístup 20. 7. 2020].

${ }^{28}$ BIEDERMANN, Hans: Lexikón symbolov. Bratislava : Obzor, 1992, s. 259 - 260.

${ }^{29}$ RULÍŠEK, Hynek: Slovník krest'anskej ikonografie. Postavy, atribúty, symboly. Praha : Karmášek, 2006, nečíslované.
} 


\section{Správy}

kazom na mladý vek. Zaujímavé je, že lupene sú naznačené červenou farbou, ktorá môže poukazovat' na jej osud. V závere je možné konštatovat', že predmetný portrét zo zbierok SSM pravdepodobne vznikol ako kópia, ktorá sa vyznačuje renesančnou statickost'ou a nie je možné ho datovat' do 18 . storočia, ale do záveru 17. storočia (okolo 1673 - 1676).

Evidentne jasným pendantom k obrazu Klaudie Felicitas je obraz s portrétom Leopolda I., ktorý je v zbierkovom fonde SSM zaradený pod ev. č. 1031. Leopold I. je zobrazený v rytierskom brnení západoeurópskeho typu. D. Učníková32 portrét datovala okolo roku 1680. Rozmery oboch obrazov sú identické, oba však boli zrezané. Zrkadlová kompozícia (situovanie drapérie) potvrdzuje pravdepodobnost', že boli vytvorené na objednávku so zámerom spoločnej prezentácie v interiéri ako reprezentačné portréty. Vzhl'adom k tomu predpokladáme, že aj portrét Leopolda I. mohol vzniknút' v identickom čase ako portrét Klaudie Felicitas.

\section{Záver}

Všetky tri portréty sú evidované v zbierkovom fonde SSM následne, čo podporuje myšlienku, že mohli byt' do zbierok múzea prevzaté z jedného zdroja. Ich datovanie, historické súvislosti a kvalita, poukazujú na previazanost' s vyššou šlachtickou spoločnost'ou a ich konexie. $V$ dobe vzniku boli jednotlivé atribúty (napr. sociálnej identity), ktoré sa na portrétoch nachádzajú, všeobecne identifikované a akceptované. Vážnost'ou tváre a tela bez pohybov (v štylizovanej forme) prezentujú vnútorný stav emocionálneho pokoja a odstupu spojeného so sebadisciplínou, kontrolou temperamentu, emócií a vášní. Portréty zachytávajú jednotlivé osobnosti so snahou o transformovanie individuálnych čŕt (reálneho fyzična), ktorými sa vyznačovali.

Personálne smerujú ku kaštiel'om v Hronseku. Je vysoko pravdepodobné, že by mohli reprezentovat' „fragment“ zbierky obrazov, ktorá doposial' nebola identifikovaná (nikdy nebola predmetom vedeckého bádania). Ako uvádza T. Janura, ${ }^{33}$ inventárne súpisy ku kaštiel'om v Hronseku doteraz neboli objavené.

Výtvarná a umelecká kvalita diel z evanjelického dreveného kostola (v zbierkach SSM sa nachádza napr. výnimočný obraz s námetom Kristova krv) aj rozsiahly cyklus nástenných malieb v tzv. Vodnom hrade

\footnotetext{
${ }^{30}$ BECKER, Udo: Slovník symbolov. Praha : Portál, 2007, s. 248.

${ }^{31}$ HALL, James: Slovník námetov a symbolov vo výtvarnom umení. Praha : Paseka, 2008, s. $390-391$.

32 UČNÍKOVÁ, D.: Historický portrét, s. 54.

${ }^{33}$ JANURA, T. a kol.: Vidiecke šl'achtické sídla v Zvolenskej stolici, s. 88 - 97.
} 
v Hronseku poukazujú na význam lokality. Jedine medziodborovým výskumom by mohli byt' vzt’ahy a súvislosti „rekonštruované“, pričom je možné využívat' aj významné poznatky $\mathrm{z}$ reštaurovania diel. V závere príspevku by sme sa chceli pod'akovat' kolegom, vd'aka ktorým sa podarilo priblížit' a doplnit' mozaiku poznatkov k predmetným portrétom: Frederikovi Federmayerovi, Martine Hrdinovej a Tomášovi Janurovi.

Miloslava Borošová Michalcová - Miroslav Slúka

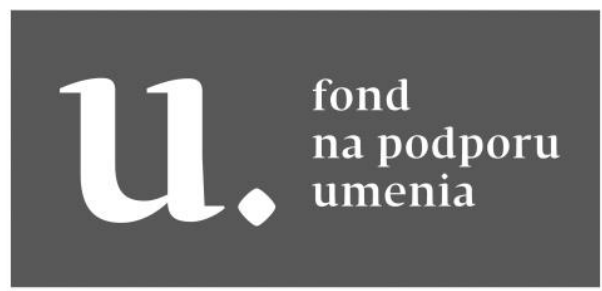


Správy

\section{Obrazová príloha}

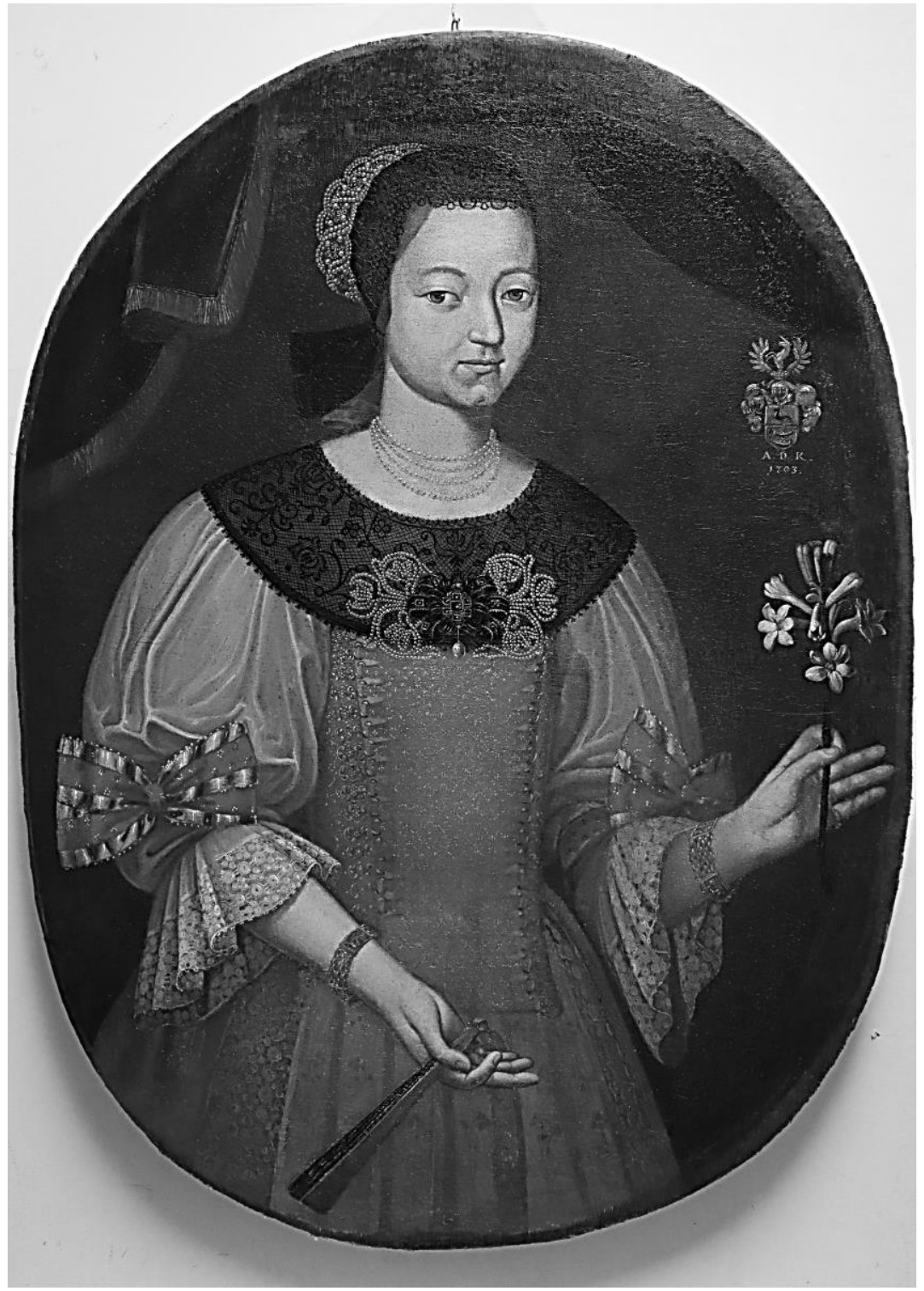

Portrét evidovaný pod č. Vu-01021. Stav po reštaurovaní.

Zdroj: Stredoslovenské múzeum. 


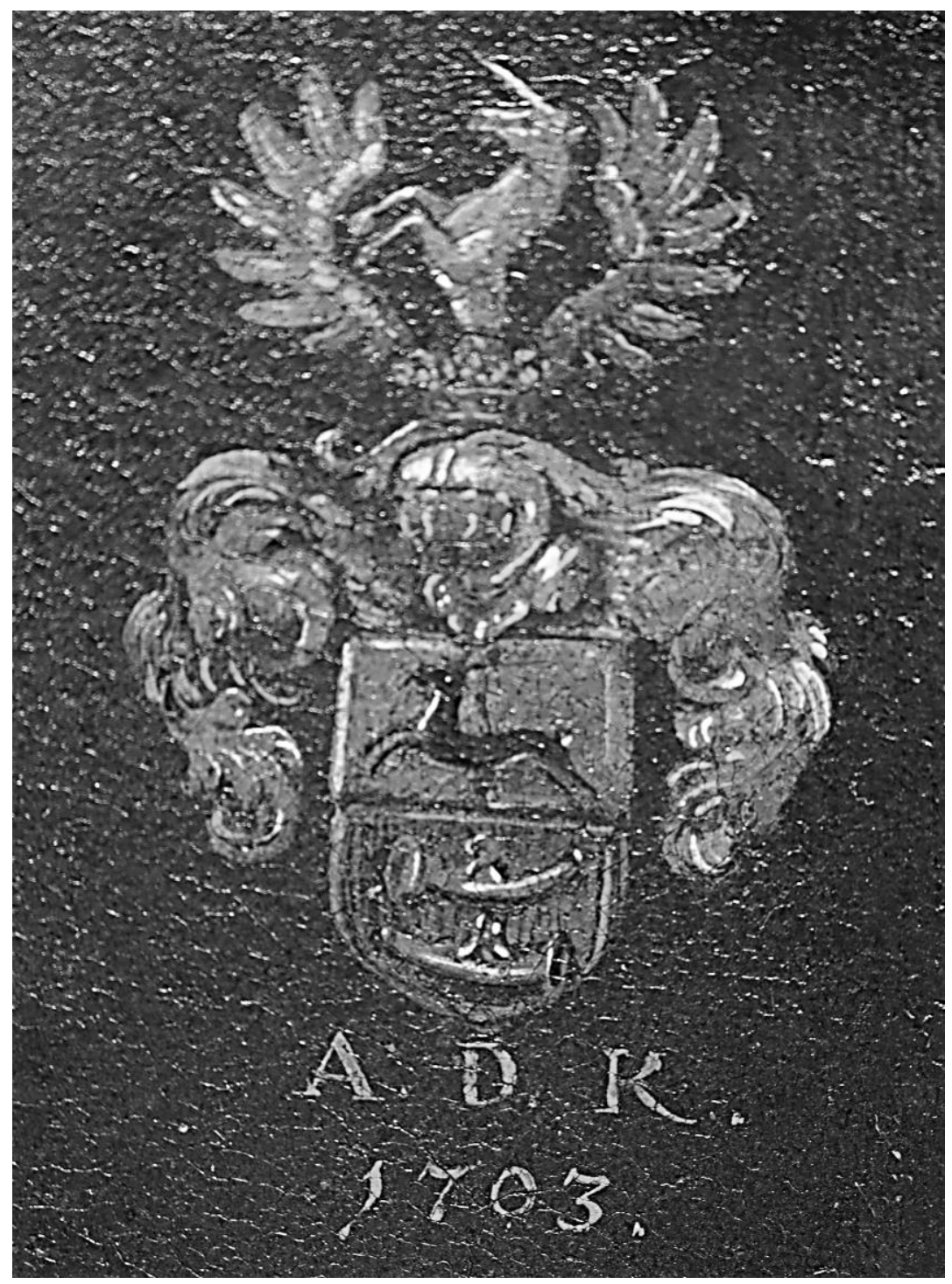

Portrét evidovaný pod č. Vu-01021. Detail erbu. Zdroj: Stredoslovenské múzeum. 


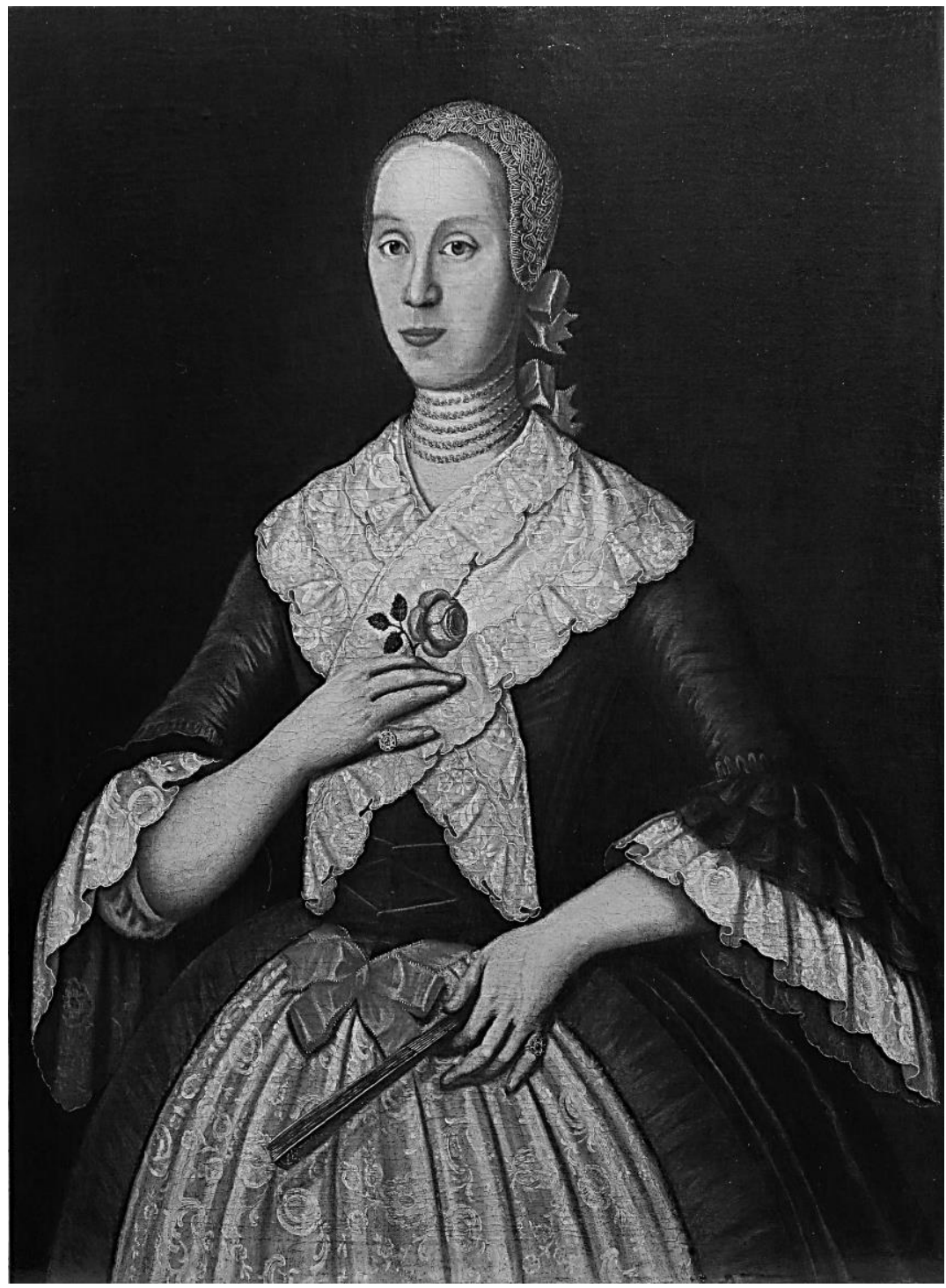

Portrét evidovaný pod č. Vu-01022. Stav po reštaurovaní. Zdroj: Stredoslovenské múzeum. 


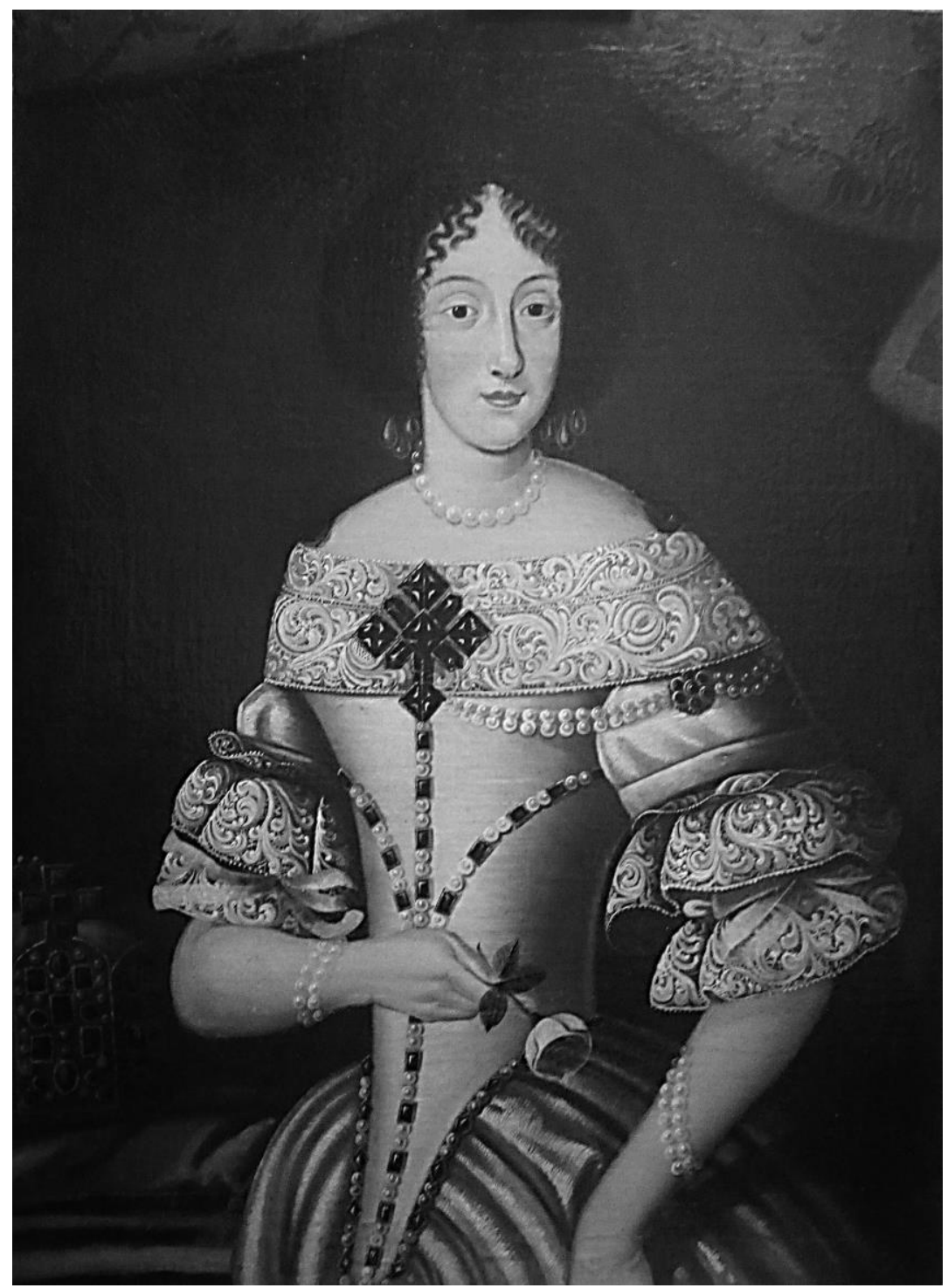

Portrét evidovaný pod č. Vu-01023. Stav po reštaurovaní.

Zdroj: Stredoslovenské múzeum. 